\title{
More than a decade of reports of rabies in herbivores and loss of bats' habitat in the state of Rondônia
}

This study aimed to conduct a retrospective study of rabies cases in herbivores in the state of Rondônia, from 2002 to 2014 , and the relation of epidemic peaks to anthropized areas of the Amazon rainforest, mainly associated with the loss of bats' natural habitat. For this purpose, data related to the species affected, month year and the geographic coordinates of the places where the cases occurred were collected. They were inserted in the Epi InfoTM 7.1.5.2 platform and QGIS Version 2.14.1 to determine Pearson frequency, distribution, regression, and linear correlation. During the period, 170 bovine animals and 19 horses were diagnosed with the disease, in 47 municipalities of the 52 existing ones. Regarding habitat loss, especially in municipalities with a high incidence of notifications, these were related to a series of forest clearance events, such as the construction of hydroelectric plants and the convergence of immigration flows to the state of Rondônia, with the expansion of the National agricultural frontier. Positive cases in herbivores were observed in all years of the study, with an average of 14 cases/year and a trend of seasonality during the rainy season. In a general context, there was a decrease of $1.9 \%$ in positive tests in relation to negative tests, each year of the period and the reduction in municipalities affected.

Keywords: Environmental factors; Amazonia; Bovine animals; Horses; Occurrence.

\section{Mais de uma década de relatos de raiva em herbívoros e perda do habitat de morcegos no estado de Rondônia}

\begin{abstract}
Este trabalho teve por objetivos realizar um estudo retrospectivo de casos de raiva em herbívoros no estado de Rondônia, durante o período de 2002 a 2014 , e a relação de picos epidêmicos com áreas antropizadas da floresta Amazônica, principalmente associadas a perda do habitat natural dos morcegos. Para tal foram coletados dados relacionados a espécie afetada, mês, ano e as coordenadas geográficas dos locais onde ocorreram os casos, e posteriormente inseridos na plataforma Epi InfoTM 7.1.5.2. e programa QGIS Versão 2.14.1 para determinar a frequência, distribuição, regressão e correlação linear de Pearson. Durante o período foram diagnosticados 170 bovinos e 19 equinos positivos para doença, em 47 municípios dos 52 existentes. Destes, Porto Velho, Ministro Andreazza, Jiparaná e Ouro Preto do Oeste foram os com maior incidência. Em relação a perda de habitat, principalmente em municípios com elevada incidência de notificações, estas, estavam relacionadas a uma série de eventos de retirada florestas, como a construção de usinas hidrelétricas e a convergência de fluxo imigratório para o Estado de Rondônia, com a expansão da fronteira agrícola Nacional. Casos positivos em herbívoros foram observados em todos os anos do estudo, com uma média de 14 casos/ano e tendência de sazonalidade durante o período chuvoso. Num contexto geral, houve um decréscimo de 1,9\% dos exames positivos em relação aos negativos, a cada ano do período ( $R 2=0,51$ e $P=0,0061)$ e a redução de municípios afetados ( $R 2=0,484$ e $p=0,0083)$.
\end{abstract}

Palavras-chave: Fatores ambientais; Amazônia; Bovinos; Equinos; Ocorrência.

Topic: Epidemiologia e Saúde Ambiental

Reviewed anonymously in the process of blind peer
Received: 02/02/2021

Approved: 27/02/2021
Rodrigo Izuro Fujihara

Universidade Federal de Rondônia, Brasil http://lattes.cnpq.br/4871372780505999 rodrigofujihara@gmail.com

Mayra Meneguelli (iD

Universidade Federal de Rondônia, Brasil http://lattes.cnpq.br/3416800480521808 http://orcid.org/0000-0002-6369-958X

mayrameneguelli@gmail.com

Ezequiel Ferreira Barbosa (iD

Universidade Federal de Rondônia, Brasil http://lattes.cnpq.br/9858204302925395 http://orcid.org/0000-0002-5371-6366 ezequielbarbos@gmail.com

\author{
Átila Bezerra de Mira \\ Universidade Federal de Rondônia, Brasil \\ http://lattes.cnpq.br/8487826290510262 \\ http://orcid.org/0000-0002-8956-0965 \\ atilaabm4@gmail.com \\ Kelly Cristina Araujo Barbosa \\ Universidade Federal de Rondônia, Brasil \\ http://lattes.cnpq.br/1178844591409388 \\ http://orcid.org/0000-0002-4791-2379 \\ kellybarbosa.mv@gmail.com \\ Francisco Carlos da Silva \\ Universidade Federal de Rondônia, Brasil \\ http://lattes.cnpq.br/9667310688430214 \\ http://orcid.org/0000-0003-4105-3806 \\ fcsbiologicalscience@gmail.com
}

Sandro Vargas Schons (iD

Universidade Federal de Rondônia, Brasi http://lattes.cnpq.br/2469714239413847 http://orcid.org/0000-0001-9811-5356 sandroschons@unir.br

\section{Referencing this:}

FUJIHARA, R. I.; MENEGUELLI, M.; BARBOSA, E. F.; MIRA, A. B.; BARBOSA, K. C. A.; SILVA, F. C.; SCHONS, S. V.. More than a decade of reports of rabies in herbivores and loss of bats' habitat in the state of Rondônia. Revista Ibero Americana de Ciências Ambientais, v.12, n.2, p.233-239, 2021. DOI: http://doi.org/10.6008/CBPC2179- 


\section{INTRODUCTION}

Rabies is an infectious and contagious disease of acute, fatal evolution, affecting the central nervous system (CNS), caused by the virus of the family Rhabdoviridae and genus Lyssavirus (LIMA et al., 2005). According to the Pan American Health Organization, four molecular variants of the rabies virus are identified in Latin America, type 3 being associated with the hematophagous bat Desmodus rotundus, a natural reservoir of the virus in the environment, and the main form of rabies transmission to herbivores. The other types are involved in insectivorous dog and bat infections (HEINEMANN et al., 2002; KOBAYASHI et al., 2006).

The bat $D$. rotundus belongs to one of the three species of hematophagous bats in existence, with a distribution from southern Mexico to Argentina and Chile. In addition to its unusual feeding habit, this species is particularly interesting for being the main transmitter of bovine rabies (MARTINS, 2008). According to Greenhall (1970), D. rotundus feeds preferentially on the blood of bovine animals, followed by other species, such as horses, goats, pigs, birds, dogs and humans, and it has become common in rural environments. Few studies have been carried out on the feeding of Desmodus in areas not occupied by humans (MARTINS, 2008).

However, the continued growth in land use has resulted in the replacement of bats from most lands in the world (BAKER et al., 2007). Many studies have shown that urbanization has a negative effect on animal species and communities, including: loss of habitat and fragmentation (SCOLOZZI et al., 2012). When replacing natural habitat or interrupting connectivity, urbanized areas and roads can significantly interfere with the movement of bats (KERTH et al., 2009).

In Rondônia, after diversified colonization cycles, the main economic activity was developed in livestock, with a herd of more than 13 million heads, raised extensively in deforested areas for the implementation of pastures. However, small fractions of forests have been maintained as permanent preservation areas (PPA), and they act as biological corridors and a place of refuge for wild species such as Desmodus rotundus.

Based on the above, this study aimed to carry out a retrospective study of cases of rabies in livestock animals in Rondônia, from 2002 to 2014, as well as to associate the epidemic peaks of the diseases with anthropized changes in the State and the loss of bats' natural habitat.

\section{MATERIALS AND METHODS}

A database was created based on disease investigation forms (Form in's) with a positive diagnosis of rabies, notified to the Agrosilvopastoril Health Defense Agency of the State of Rondonia/IDARON, during the period from 2002 to 2014. Data related to species, municipality, month, and year of outbreaks were collected and inserted in the Epi InfoTM 7.1.5.2 program platform, then analyzed for frequency and distribution. For the regression analysis and Pearson's correlation coefficients, with a significance level of $5 \%(p<0.05)$, the Biostat Pro 5.9.8 program was used. The Microsoft Excel program generated trend lines. Deforestation data were obtained from the website - - from the National Institute for Space Research - INPE regarding the 
Deforestation ${ }^{1}$ Program - PRODES that monitors deforestation in Brazil's Legal Amazon.

The maps were elaborated from the compilation and conversion of the geographical coordinates and inserted in the QGIS program Version 2.14.1-Essen for geoprocessing of the information. For the identification of conglomerates with greater intensity, the Kernel estimate was used, which allows visual analysis of the distribution of rabies outbreaks during the study period in relation to the conglomerates identified in the heat map, informing the political division of the municipalities of the State of Rondonia.

The diagnosis of rabies was performed through the Direct Immunofluorescence technique using polyclonal anti-rabies conjugate, marked by fluorescein isothiocyanate and biological tests of intracerebral inoculation in mice, as recommended by the World Health Organization (WHO).

\section{RESULTS AND DISCUSSION}

Of a total of 1,160 herbivores with clinical suspicion of rabies, $16.29 \%$ had a positive result by the direct immunofluorescence technique or biological test (Table 1), lower than those observed in states such as Minas Gerais (44.42\%) (MENEZES et al., 2008) and Goiás (22.1\%) (SANTOS et al., 2006), and higher than the states of Mato Grosso (MATTA et al., 2010), São Paulo (QUEIROZ et al., 2009) and Rio Grande do Sul (TEIXEIRA et al., 2015), with 3.5\%, 4.9\%, and 3.5\%, respectively. During the study period, swine (25/0), sheep, $(11 / 0)$ mules (3/0), goats (3/0), donkeys and buffalo (1/0) were clinically suspected; however, only bovine animals (1059/170) and horses (57/19) had positive results, totaling 189 positive cases.

Table 1: Samples from herbivores with suspected rabies sent for diagnosis between 2002 and 2014 in the state of Rondônia according to year, number and result of the immunofluorescence test, and biological proof for rabies

\begin{tabular}{|c|c|c|c|c|c|c|}
\hline \multicolumn{7}{|l|}{ SAMPLES } \\
\hline NUMBER & & & & & & \\
\hline YEAR & SENT & $\%$ & PositiVES & $\%$ & NegatiVES & $\%$ \\
\hline 2002 & 32 & 2.76 & 19 & 59.38 & 13 & 40.63 \\
\hline 2003 & 81 & 6.98 & 35 & 43.21 & 46 & 56.79 \\
\hline 2004 & 86 & 7.41 & 25 & 29.07 & 61 & 70.93 \\
\hline 2005 & 84 & 7.24 & 9 & 10.71 & 75 & 95.24 \\
\hline 2006 & 49 & 4.22 & 11 & 22.45 & 38 & 77.55 \\
\hline 2007 & 76 & 6.55 & 28 & 36.84 & 48 & 63.16 \\
\hline 2008 & 114 & 9.83 & 20 & 17.54 & 94 & 82.46 \\
\hline 2009 & 103 & 8.88 & 16 & 15.53 & 87 & 84.47 \\
\hline 2010 & 98 & 8.45 & 8 & 8.16 & 90 & 93.88 \\
\hline 2011 & 101 & 8.71 & 2 & 1.98 & 99 & 102.97 \\
\hline 2012 & 115 & 9.91 & 2 & 1.74 & 113 & 106.96 \\
\hline 2013 & 115 & 9.91 & 9 & 7.83 & 106 & 113.04 \\
\hline 2014 & 106 & 9.14 & 5 & 4.72 & 101 & 114.15 \\
\hline TOTAL & 1160 & 100 & 189 & 16.29 & 971 & 89.40 \\
\hline
\end{tabular}

In Rondônia, rabies was diagnosed in 47 out of the 52 municipalities, with a higher incidence in Porto Velho, Cacoal, Ministro Andreazza, Ji-Paraná, and Ouro Preto do Oeste, as shown in the map of the conglomerates established by Kemel estimate (Figure 1). The state of Rondônia has a history of territorial occupation based on the removal of the native forest (PIONTEKOWSKI et al., 2014). This influx caused significant changes in the natural landscape, with the replacement of native forests by (temporary and

${ }^{1}$ http://www.obt.inpe.br/prodes/prodes_1988_2015n.htm 
permanent) agriculture and cattle raising (TOURNEAU et al., 2010). Habitat loss, especially in the areas observed with the highest incidence of rabies diagnoses, may be related to a series of forest clearance events. In the surroundings of Porto Velho, for example, the construction of the Santo Antônio and Jirau Hydroelectric Plants were responsible for major changes in the habitat of humans and other animals (Figure 1). The suppression of the forest began in 2006 and ended in 2015. An estimate of deforestation and flooding area was previously calculated; however, $468 \mathrm{~km}^{2}$ of forest (lowland and non-lowland) were completely submerged during this period, exceeding the impact predictions by $160 \mathrm{~km}^{2}$ (52.0\%) (COCHRANEA et al., 2017).

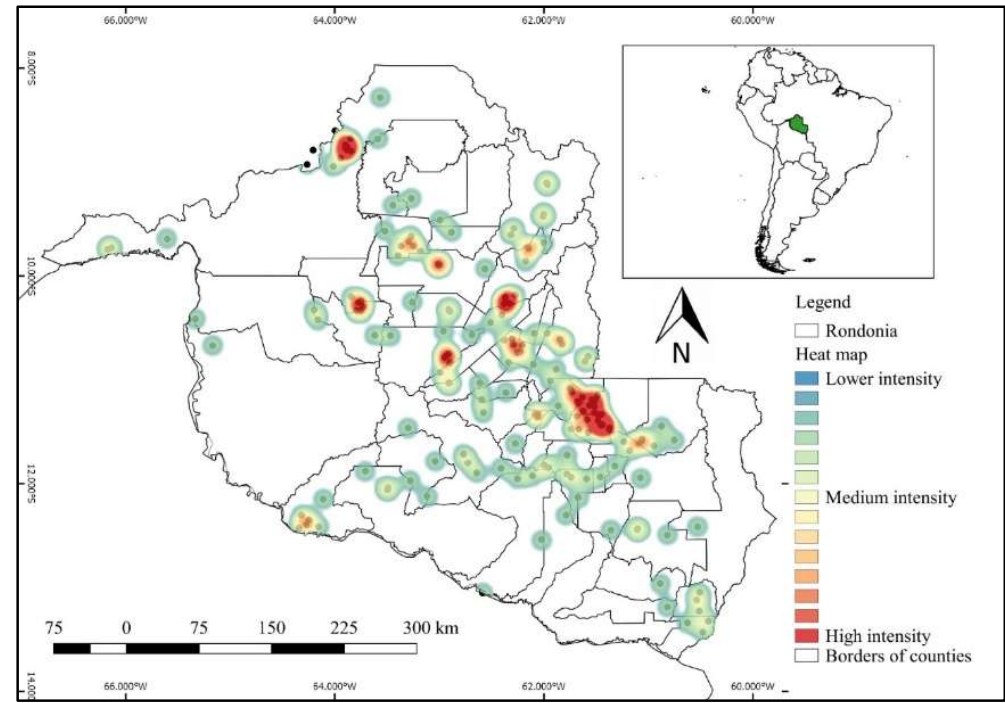

Figure 1: Distribution of positive cases of rabies in herbivores and conglomerates established by the Kernel estimate on the heatmap in the state of Rondônia, between 2002 and 2014.

The construction of the plants also had a big social impact on the populations living in the area that had a direct impact on the banks of the river. This population was removed from its place of origin and taken to new communities, expanding its territorial occupation based on the removal of the native forest. With the removal of this forest, as well as the herds, it is possible that the bat's foraging site was lost. Another alternative is also linked to habitat loss, due to demographic expansion with the arrival of new workers who have occupied these deforested areas and the absence of herds or native species, which facilitated the arrival of bats in these places. After 2008, there was a reduction in the number of positive cases, occurring only sporadically, except for Porto Velho, which maintained its endemic status.

Other regions with a high rate of notifications were the municipalities of Cacoal and Ministro Andreazza. Both have their histories linked to the expansion of the National agricultural frontier, a result of the convergence of immigration flows to the state of Rondônia. In a large part of the state, there was an expansion of the cattle herd, particularly accelerated in a strip that extends through the microregions of Cacoal, Ji-Paraná and Porto Velho, where there was an increase in more than 50 heads $/ \mathrm{km}^{2}$ (PIONTEKOWSKI et al., 2014). As a result, much of the vegetation was removed to make way for pastures.

The municipality of São Miguel do Guaporé, without diagnoses of the disease until 2008, presented four outbreaks of the disease between 2009 and 2014 (Figure 1). The appearance of rabies in this region is due to the expansion of livestock in areas surrounding the forest reserves, deforested for implantation of 
pastures and introduction of cattle. Such anthropic changes profoundly alter the ecosystem of the chiropterans, forcing them to seek new addresses and food sources and feed on herbivores, especially bovine animals (SILVA et al., 2001). The deforestation associated with a higher incidence of rabies was evidenced by the moderate correlation between the number of positive animals and the deforestation rate per year, with a decrease in the cases of the disease as the area dismantled was reduced $(r=0.6111 ; p=0.0265)$ (Figure $2 A)$.

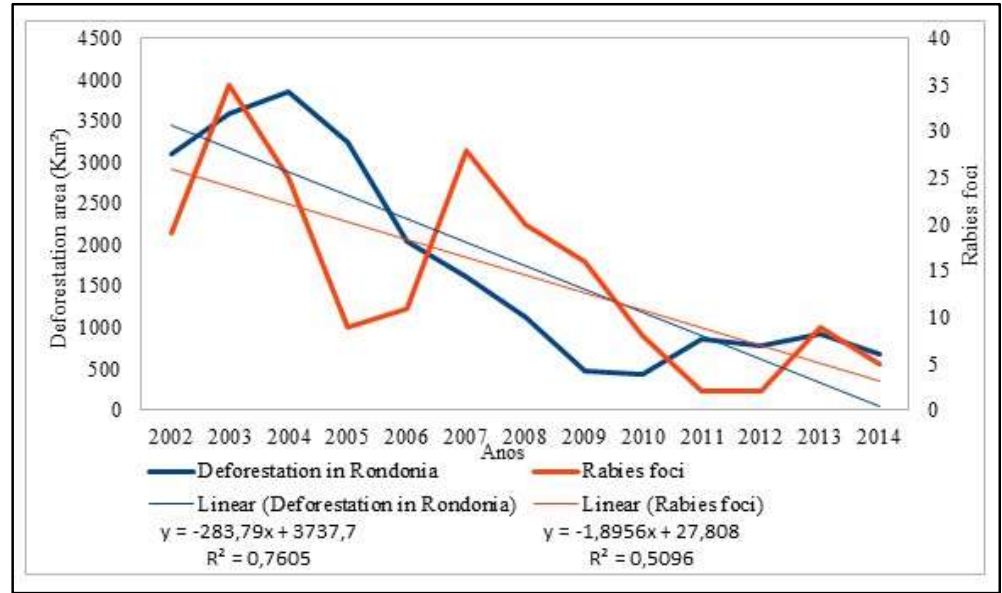

Figure 2: Relation between deforestation and outbreaks of rabies in the state of Rondônia between 2002 and 2014.

Rabies in herbivores tends to be cyclical, reappearing in periods of three to five years and is due to the increased incidence of infected hematophagous bats and, when feeding, they contaminate cattle. The interval between these peaks occurs due to the death of infected bats and the time needed to reinfect themselves (MORI et al., 1998). In the state, cases of rabies were observed in all years investigated, with an average of 14 cases/year, and two episodes of higher incidence, in 2003/2004 and 2007/2008 (Table 1). Although there was no increase in the disease after 2008, it is difficult to say that it is controlled, as there are underreporting of herbivores with signs suggestive of rabies. According to Kotait et al. (1996), for each case of the disease, 10 are not notified, producing an epidemiological scenario far from reality.

As for seasonality, positive animals were diagnosed in all months of the year; however, the rainy months, from October to April, presented the highest percentage of positive animals 59.78\% (113 cases) in comparison with the dry months, from June to August $-21.16 \%$ (40 cases). In Brazil, rabies tends to occur more frequently from April to August, due to the bats' biological cycle, during disputes between males for the female, in the spring months, when they become contaminated and spread to new colonies, contributing to the appearance of animals with clinical signs of infection as of April (SILVA et al., 2001). However, this seasonal distribution was not observed in semi-arid regions (LIMA et al., 2005), as well as in Rondônia.

In a general context, from 2002 to 2014 we observed a decrease of $1.9 \%$ positive tests in relation to negative tests, each year of the period, with linear coefficient $\mathrm{R}^{2}=0.51$ and $\mathrm{P}=0.0061$. As well as a reduction of $1.03 \%$ in the municipalities affected, according to the trend line, with linear coefficient $R^{2}=0.484$ and $\mathrm{p}=0.0083$. 


\section{CONCLUSIONS}

In Rondônia, we observed an interrelation between the number of positive cases of rabies with anthropic actions and the wild cycle of the chiropterans, with an increase in deforestation for the implantation of pastures and introduction of cattle. Climatic actions, such as the rainy season in Rondônia, showed a trend towards the seasonality of the disease. Thus, these results show the need for further studies on diseases that present neurological clinical signs and are not negative for rabies.

ACKNOWLEDGEMENTS: Agência de Fiscalização Agrosilvopastoril de Rondônia for the availability of technicians and for the data contained in the investigation forms (Form in) of herbivores and National Program of Academic Cooperation in Amazonia (PROCAD-AM).

\section{REFERENCES}

BAKER, P. J.; HARRIS, S.. Urban mammals: what does the future hold? Analysis of the factors affecting patterns of use of residential gardens in Great Britain. Mammal Review, v.37, n.4, p.297-315, 2007. DOI:

https://doi.org/10.1111/j.1365-2907.2007.00102.x

COCHRANEA, S. M. V.; MATRICARDI, E. A. T.; NUMATA, I.; LEFEBVRE, P. A.. Landsat-based analysis of mega dam flooding impacts in the Amazon compared to associated environmental impact assessments: Upper Madeira River example 2006-2015. Remote Sensing Applications: Society and Environment, v.7, p.1-8, 2017. DOI:

https://doi.org/10.1016/j.rsase.2017.04.005

GREENHALL, A. M.. The use of a precipitin test to determine host preferences of the vampire bats Desmodus rotundus and Diaemus youngi. Bijdragen tot de Dierkunde, v.40, p.3639, 1970. DOI: https://doi.org/10.1163/26660644-04001011

HEINEMANN, M. B.; FERNANDES-MATIOLI, F. M. C.; CORTEZ, A.; SOARES, R. M.; SAKAMOTO, S. M.; BERNARDI, F.; ITO, F. H.; MADEIRA, A. M. B. N.; RICHTZENHAIN, L. J.. Genealogical analyses of rabies virus strains from Brazil based on $\mathrm{N}$ gene alleles. Epidemiology and Infection, v.128, n.3, p.503-511, 2002. DOI: https://doi.org/10.1017/S095026880200688X

KERTH, G.; MELBER, M.. Species-specific barrier effects of a motorway on the habitat use of two threatened forest-living bat species. Biological Conservation, v.142, n.2, p.270-279, 2009. DOI: https://doi.org/10.1016/j.biocon.2008.10.022

KOBAYASHI, Y.; OGAWA, A.; SATO, G.; SATO, T.; ITOU, T.; SAMARA, S. I.; CARVALHO, A. A. B.; NOCITI, D. P.; ITO, F. H.; SAKAI, T.. Geographical distribution of vampire bat-related cattle rabies in Brazil. The Journal of Veterinary Medical Science, v.68, n.10, p.1097-100, 2006. DOI: http://doi.org/10.1292/jvms.68.1097

KOTAIT, I.. Infecção de morcegos pelo vírus da raiva. São Paulo: Boletim do Instituto Pasteur, v.2, n.1, p.51-58, 1996.

LIMA, E. F.; RIET-CORREA, F.; CASTRO, R. S.; GOMES, A. A. B.; LIMA, F. S.. Sinais clínicos, distribuição das lesões no sistema nervoso e epidemiologia da raiva em herbívoros na região Nordeste do Brasil. Pesquisa Veterinária Brasileira, v.25, n.4, p.250-264, 2005. DOI: http://dx.doi.org/10.1590/S0100736X2005000400011

MARTINS, F. M.. Filogeografia intraespecífica do morcego hematófago Desmodus rotundus (Chiroptera, Phyllostomidade). Tese (Doutorado em Biologia) Universidade de São Paulo, São Paulo, 2008. DOI: http://doi.org/10.11606/T.41.2008.tde-05092008-114747

MATTA, G. C. A.; NOCITI, D. L. P.; CARVALHO, A. A. B.; NOCITI, R. P.; SAMARA, S. I.. Caracterização epidemiológica da raiva bovina no Estado de Mato Grosso, Brasil, no período de 1996 a 2006. Arquivos do Instituto Biológico, São Paulo, v.77, n.4, p.601-607, 2010.

MENEZES, F. L.; SILVA, J. A.; MOREIRA, E. C.; MENESES, J. N. C.; MAGALHÃES, D. F.; BARBOSA, A. D.; OLIVEIRA, C. S. F.. Distribuição espaço-temporal da raiva bovina em Minas Gerais, 1998 a 2006. Arquivo Brasileiro de Medicina Veterinária e Zootecnia, v.60, n.3, p.566-573, 2008. DOI: https://doi.org/10.1590/\$0102-09352008000300007

MORI, A. E.; LEMOS, R. A. A.. Raiva. In: LEMOS, R. A. A. Principais enfermidades de bovinos de corte do Mato Grasso do Sul: reconhecimento e diagnóstico. Campo Grande: UFMS, 1998. p.47-58.

PIONTEKOWSKI, V. J.; MATRICARDI, E. A. T.; PEDLOWSKI, M. A.; FERNANDES, L. C.. Avaliação do Desmatamento no Estado de Rondônia entre 2001 e 2011. Floresta e Ambiente, v.21, n.3, p.297-306, 2014. DOI: http://dx.doi.org/10.1590/21798087.068213

QUEIROZ, L. H.; CARVALHO, C.; BUSO, D. S.; FERRARI, C. I. L.; PEDRO, W. A.. Perfil epidemiológico da raiva na região Noroeste do Estado de São Paulo no período de 1993 a 2007. Revista da Sociedade Brasileira de Medicina Tropical, Uberaba, v.42, n.1, p.9-14. 2009.

SANTOS, M. F. C.; RESENDE, R. M.; NEVES SOBRINHO, R.; VIEIRA, S.. Diagnóstico laboratorial da raiva no Estado de Goiás no período de 1976 a 2001. Ciência Animal Brasileira, v.7, n.1, p.77-83, 2006. 
SCOLOZZI, R.; GENELETTI, D.. A multi-scale qualitative approach to assess the impact of urbanization on natural habitats and their connectivity. Environmental Impact Assessment Review, v.36, n.1, p.9-22, 2012. DOI: https://doi.org/10.1016/j.eiar.2012.03.001

SILVA, J. A.; MOREIRA, E. C.; HADDAD, J. P. A.; SAMPAIO, I. B. M.; MODENA, C. M.; TUBALDINI, M. A. S.. Uso da terra como determinante da distribuição da raiva bovina em Minas Gerais, Brasil. Arquivo Brasileiro de Medicina Veterinária e Zootecnia, Belo Horizonte, v.53, n.3, p.273-283, 2001. DOI: https://doi.org/10.1590/S0102-09352001000300002
TEIXEIRA, L. H. M.; TOMAZ, L. A. G.; LINHARES, G. F. C.; SANTOS, M. F. C.; JAYME, V. S.. Distribuição espaço-temporal dos diagnósticos laboratoriais da raiva animal. Ciência Animal Brasileira, Goiânia, v.16, n.1, p.144-157, 2015. DOI: http://dx.doi.org/10.1590/1809-6891v16i131282

TOURNEAU, F. M.; BURSZTYN, M.. Assentamentos rurais na Amazônia: contradições entre a política agrária e a política ambiental. Ambiente \& Sociedade, Campinas, v.13, n.1, p.111-130, 2010.

A CBPC - Companhia Brasileira de Produção Científica (CNPJ: 11.221.422/0001-03) detém os direitos materiais desta publicação. Os direitos referem-se à publicação do trabalho em qualquer parte do mundo, incluindo os direitos às renovações, expansões e disseminações da contribuição, bem como outros direitos subsidiários. Todos os trabalhos publicados eletronicamente poderão posteriormente ser publicados em coletâneas impressas sob coordenação da Sustenere Publishing, da Companhia Brasileira de Produção Científica e seus parceiros autorizados. Os (as) autores (as) preservam os direitos autorais, mas não têm permissão para a publicação da contribuição em outro meio, impresso ou digital, em português ou em tradução. 